\title{
KEGIATAN TARI KREASI MANUK DADALI \\ UNTUK MENINGKATKAN KECERDASAN KINESTETIK ANAK KELOMPOK B DI TK ARTANITA AL- KHAIRIYAH KOTA TASIKMALAYA
}

\author{
Aan Darwati ${ }^{1}$, Heri Yusuf Muslihin ${ }^{2}$, Rosarina Giyartini ${ }^{3}$ \\ ${ }^{1}$ Program Studi PGPAUD UPI Kampus Tasikmalaya \\ ${ }^{2}$ Program Studi PGPAUD UPI Kampus Tasikmalaya \\ ${ }^{3}$ Program Studi PGPAUD UPI Kampus Tasikmalaya
}

Email: heriyusuf@upi.edu

(Received: Nopember 2019; Accepted: Nopember 2019; Published: Desember 2019)

\begin{abstract}
Kinestetik Intelligence especially in gross motor development is one that need to be considered by all parties, especially the elderly because of its urgency in the growth of early child development. Problems found in Group B in TK Artanita Al-Khairiyah Tasikmalaya still low motoric crude child skills caused by learning that is still cause by learning that is still conventional. The purpose of this study to improve gross motor of early childhood dance creation manuk dadali. The method used that is research action class Kemmis dan Mc Taggart. The first indicator is flexibility which has significant raising. The final ability is $15,4 \%$ in the criteria of development as the expectation and $84,6 \%$ in the criteria of great development. The second indicator is balance which increases with the final ability is $38 \%$ in the criteria of development as the expectation and $61,5 \%$ in the criteria of great development. The third indicator is agility which increases with the final ability is $30,8 \%$ in the criteria of development as the expectation and 69,2\% in the criteria of great development. The fourth indicator is coordination of eyes and foot movement which increases with the final ability is $7,7 \%$ in the criteria of beginning development, 38,5\% in the criteria of development as the expectation, and 53,8\% in the criteria of great development. Moreover, for the fifth indicator; coordination of hands and head movement increases with the final ability is $23,1 \%$ in the criteria of development as the expectation and $76,9 \%$ in the criteria of great development.
\end{abstract}

Keywords: Early childhood, kinesthetic intelligence, dance creations manuk dadali.

\begin{abstract}
ABSTRAK
Kecerdasan kinestetik khususnya dalam perkembangan motorik kasar merupakan salahsatu yang perlu diperhatikan oleh semua pihak khususnya orangtua karena urgensinya dalam tumbuh kembang anak usia dini. Masalah yang ditemukan pada kelompok B di TK Artanita Al-Khairiyah Kota Tasikmalaya masih rendahnya keterampilan motorik kasar anak yang salah satunya disebabkan pembelajaran masih konvensional. Tujuan dari penelitian ini yaitu untuk meningkatkan kecerdasan kinestetik khususnya pada motorik kasar yaitu dengan tari kreasi baru manuk dadali. Metode yang digunakan yaitu penelitian tindakan kelas model Kemmis dan Mc Taggart. Kecerdasan kinestetik anak pada aspek motorik kasar anak mengalami peningkatan pada setiap indikatornya. Indikator yang pertama yaitu kelenturan mengalami peningkatan yang signifikan dengan kemampuan akhir 15,4\% pada kriteria berkembang sesuai harapan dan sebesar 84,6\% pada kriteria berkembang sangat baik. Indikator yang kedua yaitu Keseimbangan mengalami peningkatan dengan kemampuan akhir sebesar $38,5 \%$ pada kriteria berkembang sesuai harapan, dan $61,5 \%$ pada kriteri berkembang sangat baik. Indikator yang ketiga kelincahan mengalami peningkatan dengan kemampuan akhir sebesar 30,8\% pada kriteria berkembang sesuai harapan, dan sebesar $69,2 \%$ pada kriteria berkembang sangat baik. Indikator yang ke empat yaitu koordinasi gerakan mata-kaki mengalami peningkatan dengan kemampuan akhir sebesar 7,7\% pada kriteria mulai berkembang, 38,5\% pada kriteria berkembang sesuai harapan, dan 53,8\% pada kriteri berkembang sangat baik. Begitupun dengan indikator yang ke lima koordinasi gerakan tangan-kepala mangalami peningkatan dengan kemampuan akhir anak sebesar $23,1 \%$ pada kriteria berkembang sesuai harapan, dan 76,9\% pada kritetia berkembang sangat baik.
\end{abstract}

Kata Kunci: anak usia dini, kecerdasan kinestetik, tari kreasi manuk dadali. 


\section{PENDAHULUAN}

\section{Latar Belakang}

Pendidikan adalah pembelajaran, pengetahuan, keterampilan, dan kebiasaan sekelompok orang yang diturunkan dari satu generasi ke generasi berikutnya melalui pengajaran, pelatihan, atau penelitian. Pendidikan di indonesia dibagi kedalam empat jenjang pendidikan, yaitu pendidikan prasekolah, pendidikan dasar, pendidikan menengah, dan pendidikan tinggi. Pendidikan prasekolah atau sering juga disebut Pendidikan Anak Usia Dini (PAUD) diartikan sebagai jenjang pendidikan sebelum jenjang pendidikan dasar yang merupakan suatu pembinaan yang ditujukan bagi anak sejak lahir sampai dengan usia enam tahun yang dilakukan melalui pemberian rangsangan pendidikan untuk membantu pertumbuhan dan perkembangan jasmani dan rohani agar anak memiliki kesiapan dalam memasuki pendidikan lebih lanjut, yang diselenggarakan pada jalur formal, non formal, dan informal. Menurut Sujiono (2013) mengatakan:

Pendidikan anak usia dini adalah pemberian upaya dan stimulasi, membimbing, mengasuh dan pemberian kegiatan pembelajaran yang akan menghasilkan kemampuan dan keterampilan anak. Pendidikan anak usia dini merupakan sebuah pendidikan yang dilakukan pada anak yang baru lahir sampai dengan delapan tahun. (hlm. 7)

Pada usia prasekolah anak berada dalam masa usia emas atau golden age, dimana pada rentan usia 0-6 tahun ini anak mulai peka menerima berbagai stimulus. "Pada masa golden age ini proses pertumbuhan dan perkembangan anak berkembang sangat pesat dalam berbagai aspek" (Sujiono, 2013, hlm. 6). Adapun aspek perkembangan yang harus dioptmalkan meliputi: aspek nilai agama dan moral, fisik-motorik, kognitif, bahasa, sosial emosional, dan seni.

Supaya masa ini dapat dilalui dengan baik oleh anak, maka perlu diupayakan pendidikan yang tepat agar terciptanya pertumbuhan dan perkembangan yang optimal. Perkembangan fisik motorik merupakan salah satu aspek perkembangan yang penting untuk anak. Hal ini sejalan dengan pendapat Myrnawati CH, dkk (2017) mengemukakan bahwa:

One aspect of child development that need to be optimized from an early child-hood is gross motor skills, because is existence is essential to maximize growth and development of the child's body that further supporting the optimization of another aspect development. (hlm 53).

Pendapat tersebut menjelaskan bahwa salah satu aspek perkembangan anak yang perlu dioptimalkan dari anak usia dini adalah keterampilan motorik kasar, karena keberadaannya sangat penting untuk memaksimalkan pertumbuhan dan perkembangan tubuh anak yang mendukung optimalisasi pengembangan aspek lainnya.

Setiap anak sudah memiliki kecerdasan sejak lahir, sejalan dengan pendapat Imroatun Khasanah (2016, hlm. 293) mengemukakan bahwa "Kecerdasan sudah dimiliki anak sejak lahir hingga dewasa, pengembangan kecerdasan harus diberikan sejak anak dilahirkan melalui stimulasi panca indranya". Howard Gardner mengemukakan 8 kecerdasan yaitu terdiri dari kecerdasan linguistik, kecerdasan logika matemamtika, kecerdasan spasial, kecerdasan musikal, kecerdasan intrapersional, kecerdasan naturalis, kecerdasan spiritual, dan kecerdasan fisik/ kinestetik,. Salah satunya dalam mengembangkan kecerdasan kinestetik yang merupakan kemampuan dalam melakukan gerakan-gerakan yang bagus, menggunakan keterampilan fisik dalam mengkoordinasi seluruh tubuhnya dalam melakukan aktivitas untuk mengekspresikan ide dan perasaannya. Michelaki (2016, hlm.23) mengemukakan pengertian kecerdasan kinestetik "Bodily kinesthetic intelligence is defined as the ability of the individual to use his body to solve problems, express ideas and emotions and manipulate objects". Pendapat tersebut 
menjelaskan bahwa kecerdasan kinestetik tubuh sebagai kemampuan individu untuk menggunakan tubuhnya untuk memecahkan masalah, mengekspresikan gagasan dan emosi dan memanipulasi objek. untuk itu dalam menstimulus kecerdasan anak, guru atau orang tua harus lebih teliti dalam merancang metode yang tepat untuk anak

Dalam Peraturan Mentri Pendidikan dan Kebudayaan Republik Indonesia No.137 tahun 2014 tentang Standar Nasional Pendidikan Usia Dini, mengenai Satuan Tingkat Pencapaian Perkembnagan Anak (STPPA), pada aspek motorik kasar bahwa anak usia lima sampai enam tahun salah satuya anak harus mampu melakukan gerakan tubuh secara terkoordinasi untuk melatih kelenturan, keseimbangan, dan kelincahan, dan melakukan koordinasi gerakan mata-kaki-tangan-kepala.

$$
\text { Melihat di lapangan pada }
$$
kenyataannya masih rendah dalam upaya mengembangkan motorik, khususnya motorik kasar. Motorik kasar adalah kemampuan anak yang digunakan untuk mengontrol oto-otot besar, meliputi kemampuannya untuk duduk, berjalan, berlari menendang, melompat, melempar, dan sebagainya. Anak yang aktif dan cerdas kinestetik yaitu anak yang memiliki gerak tubuh yang aktif, maka dari itu stimulus yang diberikan perlu dioptimalkan. Apabila anak kurang distimulus motoriknya, maka anak tersebut akan kurang aktif bergerak. Dampak yang terjadi akan mengurangi rasa percaya dirinya.

Salah satu permasalahan yang dihadapi pada proses pembelajaran di TK Artanita AlKhairiyah adalah kondisi pembelajaran yang masih konvensional dan kurang menyentuh motorik kasar anak itu sendiri. Hal ini teridentifikasi dari hasil observasi data anak secara langsung yang dibantu guru kelas kelompok B. pada saat kegiatan observasi pra tindakan yang dilakukan pada seluruh anak kelompok B TK Artanita Al-Khairiyah kota Tasikmalaya keterampilan motorik kasarnya masih menunjukan di bawah kriteria ketuntasan minimal yang ditetapkan. Hal tersebut terlihat dari belum mampunya anak melakukan kegiatan keterampilan motorik kasar dengan benar seperti ketika meloncat anak masih sulit mengatur keseimbangannya, anak masih belum bisa mengatur koordinasi gerakan tangan dan mata ketika melakukan kegiatan tari, ketika berlari anak masih sulit untuk mengontrol kecepatan, dan sebagainya. Apabila permasalahan tersebut tidak segera diperbaiki maka akan mengganggu perkembangan anak selanjutnya.

Berdasarkan asumsi itulah yang kemudian mendorong peneliti untuk memperbaiki proses pembelajaran anak kelompok B TK Artanita Al-Khairiyah menggunakan kegiatan yang mampu merangsang kinestetik anak sehingga dapat memperbaiki khususnya dalam bidang keterampilan motorik kasar.

Peneliti berupaya menemukan solusi pemecahan masalah tersebut melalui suatu penelitian ilmiah yang berbentuk Penelitian Tindakan Kelas (PTK). Menurut peneliti salah satu kegiatan yang dapat dilakukan untuk menstimulus kecerdasan kinestetik antara lain dengan kegiatan tari. Menurut Hibana (dalam Yulesti, 2014, hlm. ) Kecerdasan kinestetik pada anak usia 5-6 tahun sangat berpengaruh dalam gerak tari, karena dengan gerakangerakan tari kreasi ini anak akan mengeluarkan tenaga. Sejalan dengan pendapat Blumenfels (dalam Michelaki, 2016, hlm. 23) mengemukakan bahwa "Educationally, dance can offer a unique body of knowlwdge and practice, relating to bodily- kinesthetic intelligence, wich dancer have an excellent ability to employ". Pendapat tersebut menjelaskan bahwa, dalam dunia pendidikan, tari dapat menawarkan suatu bentuk pengetahuan dan praktik yang unik, tari juga berhubungan dengan kecerdasan kinestetik, dimana seorang penari memiliki kemampuan yang sangat baik untuk dipekerjakan.

Tari kreasi manuk dadali di sini disesuaikan dengan perkembangan anak usia dini, karena menari khususnya tari kreasi adalah salah satu kegiatan yang aktivitasnya merupakan aktivitas gerak fisik, diharapkan dengan adanya kegiatan tari kreasi ini kecerdasan kinestetik khususnya pada kemampuan motorik kasar anak usia 5-6 tahun 
di TK Artanita Al-Khairiyah Kota Tasikmalaya meningkat.

Berdasarkan latar belakang di atas penulis tertarik untuk melakukan penelitian tindakan kelas (PTK) pada anak usia 5-6 tahun di TK Artanita dengan judul "Kegiatan Tari Kreasi Manuk Dadali untuk Meningkatkan Kecerdasan Kinestetik Anak Kelompok B di TK Artanita Al-Khairiyah “.

\section{Rumusan Masalah}

Adapun rumusan masalah dalam penelitian ini adalah:

1) Bagaimana peningkatan kemampuan guru dalam merancang pembelajaran melalui kegiatan tari kreasi manuk dadali untuk meningkatkan kecerdasan kinestetik anak kelompok B di TK Artanita Al-Khairiyah Kota Tasikmalaya?

2) Bagaimana peningkatan kemampuan guru dalam pelaksanaan kegiatan tari kreasi manuk dadali untuk meningkatkan kecerdasan kinestetik anak kelompok B di TK Artanita Al-Khairiyah Kota Tasikmalaya?

Bagaimana peningkatan kecerdasan kinestetik anak melalui kegiatan tari kreasi manuk dadali anak kelompok B di TK Artanita AlKhairiyah Kota Tasikm

\section{Tujuan Penelitian}

1) Untuk mengetahui peningkatan kemampuan guru dalam merancang perencanaan pembelajaran dengan menggunakan kegiatan tari kreasi manuk dadali untuk meningkatkan kecerdasan kinestetik anak kelompok B di TK Artanita Al-Khairiyah Kota Tasikmalaya.

2) Untuk mengetahahui peningkatan kemampuan guru dalam pelaksanaan kegiatan tari kreasi manuk dadali untuk meningkatkan kecerdasan kinestetik anak kelompok B di TK Artanita Al-Khairiyah Kota Tasikmalaya.

3) Untuk mengetahui peningkatan kecerdasan kinestetik anak dengan menggunakan kegiatan tari kreasi manuk dadali anak kelompok B di TK Artanita Al-Khairiyah Kota Tasikmalaya.

\section{Manfaat Penelitian}

Manfaat Teoritis
Secara teoritis hasil penelitian ini dapat diharapkan untuk memberikan informasi serta membantu peneliti selanjutnya terutama terhadap peningkatan kecerdasan kinestetik anak melalui tari manuk dadali.

\section{Manfaat Praktis}

1) Informasi bagi guru, untuk memberikan informasi pada guru tentang peningkatan kecerdasan kinestetik anak melalui tarian.

2) Informasi untuk siswa, untuk memberikan informasi pada siswa tentang penggunaan kegiatan tari dalam meningkatkan kecerdasan kinestetik anak.

3) Masukan kepada kepala sekolah untuk memfasilitasi guru dalam mengembangkan kecerdasan kinestetik anak

\section{TINJAUAN PUSTAKA \\ Hakikat Anak Usia Dini}

Anak usia adalah sosok individu yang berada dalam tahap pertumbuhan dan perkembangan. Sujiono (2013, hlm. 6) mengatakan bahwa "Anak usia dini adalah sosok individu yang sedang menjalani suatu proses perkembangan dengan pesat dan fundamental bagi kehidupan selanjutnya". Anak usia dini berada pada rentang usia 0-8 tahun. Menurut WHO (2012, hlm. 11) menjelaskan "Early childhood spans the prenatal period to eight years of age it is the most intensive period of brain development throughout the lifespan and therefore is the most critical stage of human development". Masa kanak-kanak berada pada rentang usia sejak lahir hingga usia delapan tahun. Masa kanak-kanak merupakan periode perkembangan paling intensif sepanjang hidupnya dan periode paling kritis dalam masa kehidupan. Berk (dalam Sujiono, 2013, hlm. 06) mengemukakan "Pada masa ini proses pertumbuhan dan perkembangan dalam berbagai aspek sedang mengalami perkembangan yang cepat semasa hidup manusia". Anak usia dini itu unik, setiap anak memiliki ciri khas yang tidak sama dengan orang dewasa. Anak usia dini cenderung selalu aktif dan memiliki rasa ingin tahu yang besar terhadap apa yang anak lihat, dengar dan 
dirasakan. Untuk itu orang tua atau orang dewasa perlu mendampingi anak supaya halhal yang dieksplorasi anak lebih bermakna. Salah satu cara yang dapat diberikan yaitu dengan memberikan rangsangan pendidikan.

\section{Tari Kreasi Manuk Dadali Pengertian Tari Kreasi}

Seni tari merupakan salah satu warisan kebudayaan Indonesia, yang harus dikembangkan dan dilestarikan selaras dengan masyarakat yang selalu mengalami perubahan. Mulyani, N (2016, hlm. 49) menyatakan bahwa "Tari dalam artian yang sederhana adalah gerak yang indah dan lahir dari tubuh yang bergerak dan berirama". Sejalan dengan pendapat Astuti, f. (2016, hlm. 6) mengemukakan bahwa "Tari merupakan ekspresi jiwa manusia, yang diungkapkan melalui gerak ritmis yang indah dalam dimensi ruang dan waktu"..

Berdasarkan pengertian tari di atas dapat disimpulkan bahwa tari adalah ungkapan ekspresi perasaan manusia yang diubah oleh imajinasi dibentuk media gerak sehingga menjadi wujud gerak simbolis sebagai ungkapan koreografernya.

Tari kreasi atau tari kreasi baru adalah tari yang telah mengalami pengembangan atau bertolak dari pola-pola tari yang sudah ada sebelumnya. Tari kreasi baru merupakan garapan baru yang mempunyai kebebasan dalam mengungkapkan gerak (Mulyani, 2016, hlm). Menurut Soedarsono (1977, hlm. 19) mengemukakan bahwa "Tari kreasi yaitu tarian yang mempunyai keindahan tersendiri dari sang koreografer dimana dalam penciptaannya berbeda dengan koreografer yang satu dengan yang lain". Tari kreasi baru terbagi menjadi dua yaitu tari kreasi baru yang berpolakan tradisi dan non tradisi. Tari kreasi baru yang berpolakan tradisi yaitu tari yang penggarapannya masih menuruti kaidah-kaidah budaya tradisinya, baik dalam musik, rias, koreografi, maupun tata teknik pentasnya, sehingga tidak menghilangkan esensi ketradisiannya. Tari kreasi baru non tradisi yaitu tari yang penggarapannya tidak menggunakan pola-pola tradisi. Tarian ini disebut juga tari modern atau tari berdasarkan tema.

Tari dalam perkembangan anak hakikatnya adalah gerak. Kemampuan gerak orang dewasa jauh berbeda dengan kemampuan gerak anak. Mulyani (2016, hlm. 64) mengemukakan bahwa "Salah satu bentuk tarian untuk pengembangan motorik kasar anak yaitu tari kreasi. Tari kreasi baru di desain untuk mengembangkan potensi anak dan untuk meningkatkan perkembangan anak, khususnya perkembangan motorik anak". Tari untuk anak disesuaikan dengan usia, karena usia menentukan perkembangan yang harus dicapai. Tari kreasi baru yang digunakan pada tarian ini adalah tari kreasi baru yang berpolakan tardisi.

\section{Karakteristik Tari Kreasi Anak Usia Dini}

Tari anak usia dini merupakan ungkapan ekspresi jiwa manusia yang berupa gerak sederhana yang rimtis dan indah dengan tema-tema dan pendekatan yang sesuai dengan tahap perkembangannya. Gerakan dalam seni tari anak-anak tentunya sangat berbeda dengan seni tari orang dewasa. Karakteristik gerak tari untuk anak usia dini harus mewakili dunia anak, yang penuh dengan kegembiraan dan kesenangan. Mulyani (2016, hlm. 68) menguraikan karakteristik gerakan tari pendidikan anak usia dini sebagai berikut: tema atau judul tari harus dekat dengan kehidupan anak-anak, bentuk gerakan harus yang sederhana, diiringi dengan musik yang gembira.

Karakteristik gerak tari anak usia dini menurut Waraningtyas, P (2011, hlm. 24) antara lain adalah:

1) Biasanya bersifat maknawi/ bertema.

2) Menirukan gerakan orang tua dan orangorang disekelilingnya.

3) Kadang meniru gerakan binatang.

4) Tema tari anak dapat diperoleh dari tematema yang di senangi anak-anak.

5) Bentuk gerakan biasanya lincah, menggambarkan kegembiraan anak.

6) Musik pengiring tari menggambarkan keceriaan dan kegembiraan, bisa berasal dari lagu-lagu sederhana yag mudah diingat. 
7) Susunan gerakannya sederhana dan mudah diingat anak.

8) Biasanya dilakukan berulang-ulang.

Berdasarkan pendapat di atas dapat disimpulkan bahwa karakteristik gerak tari anak usia dini adalah gerakan bertema yang sederhana. Menirukan gerakan orang lain dapat dipelajari dengan mudah karena sesuai dengan tahap kemampuan anak yaitu meniru.

\section{Manfaat Tari bagi Anak Usia Dini}

Tari adalah salah satu media yang dapat memberikan informasi (pembelajaran) dalam menumbuhkan pengalaman baru. Maka sangatlah tepat dalam memperkenalkan tari sebagai pembelajaran yang berguna dan bermanfaat bagi anak usia dini. Sejalan dengan pendapat Aris Setiawan ( 2014, hlm. 56) mengemukakan bahwa, "Dengan belajar menari anak dapat memiliki keterampilan dan membangun hubungan social". Menurut Hidayat, R (2009) manfaat yang diperoleh ketika anak belajar menari:

1) Fungsi pembiasaan mekanisasi tubuh.

2) Fungsi pembentukan tubuh (forming body).

3) Fungsi sosialisasi diri.

4) Fungsi pembentukan kepribadian.

5) Fungsi pembentukan karakteristik diri (perwatakan).

6) Fungsi komunikasi.

7) Menyatakan gagasan non verbal.

8) Fungsi penanaman nilai budaya.

Mulyani (2016, hlm. 88-104) mengemukakan bahwa fungsi seni tari bagi anak usia dini yaitu membantu perkembangan dasar anak, mengembangkan kreativitas anak, mengembangkan bakat dan minat anak, melestarikan budaya inonesia.

Dari pendapat di atas dapat disimpulkan bahwa menari dapat memberikan manfaat yang besar bagi kehidupan anak, dengan menari anak dapat melatih kecerdasan kinestetik yang telah dimiliki. Selain itu memalui kegiatan menari anak dapat bersosialisasi dengan orang lain, dan mengenal budaya.

Kegiatan Tari Kreasi Manuk Dadali Pada
Kegiatan Pembelajaran
Manuk Dadali adalah lagu tradisioanl berasal dari Jawa Barat, lagu ini berbahasa Sunda yang diciptakan oleh Sambas Mangundikarta. Manuk dadali yang dalam bahasa Indonesia berarti burung garuda, lagu ini melukiskan burung garuda yang gagah berani, dihormati, dan mempersatukan rakyat. Sehingga menjadi lambang Negara Indonesia.

Tari manuk dadali merupakan salah satu jenis tari kreasi baru. Tari kreasi baru adalah tarian yang menpunyai keindahan tersendiri dari sang koreografer dimana dalam penciptaannya berbeda dengan koreografer yang satu dengan yang lain. Tari kreasi baru yang digunakan dalam penelitian ini yang berpolakan tradisi. Mulyani, ( 2016, hlm. 64) mengemukakan bahwa tari kreasi baru yang berpolakan tradisi yaitu "Tari yang penggarapannya masih menuruti kaidah-kaidah budaya tradisinya, baik dalam musik, rias, koreografi, maupun tata teknik pentasnya, sehingga tidak menghilangkan esensi ketradisiannya". Tarian ini diciptakan sesuai dengan karakteristik gerak tari untuk anak usia dini, tidak ada teori yang relevan tentang tari manuk dadali ini karena tari ini merupakan garapan baru diciptakan untuk memberi inovasi dalam dunia pendidikan. Koreografer dalam tari manuk dadali disini yaitu peneliti sendiri. Peneliti menciptakan sendiri gerakan dalam tarian ini sesuai dengan karakteristik gerak tari anak usia dini. Peneliti mempunyai harapan dengan gerakan yang diciptakan melalui tari manuk dadali ini akan meningkatkan kecerdasan kinestetik anak. Gerak tarian yang sederhana dengan lirik lagu yang mudah dihafalkan oleh anak akan memudahkan anak dalam mengingat gerakan tari manuk dadali.

Berikut ini adalah gerakan dalam tarian manuk dadali:

1) Gerakan pertama, kaki agak ditekuk (kuda-kuda) sambil mengayunkan kedua lengan.

2) Gerakan kedua, berjalan maju sambil kaki di jinjit dan berjalan mundur, kedua lengan diayun dan pinggang juga diayun ke kanan dan ke kiri. 
3) Gerakan ketiga, berjalan maju mundur sambil mengubah arah putaran, kedua lengan diayun.

4) Gerakan keempat, kaki melompat ke kanan dan ke kiri secara bergantian sambil mengayunkan kedua lengan.

5) Gerakan kelima, kaki diayun ke depan secara bergantian, lalu mata mengikuti arah kaki.

6) Gerakan keenam, melakukan gerakan sembada (meletakan tangan di bagian dada dengan posisi tangan yang dilipat menjadi satu) sambil kaki ditekuk dan kepala mengikuti arah tangan yang digerakan ke depan, ke kanan, dan ke kiri.

\section{Kecerdasan Kinestetik Anak Usia Dini.}

Pengertian Kecerdasan Kinestetik

Imam Suhaimi (2017, hlm. 74) mengemukakan bahwa kecerdasan kinestetik adalah "Kemampuan seseorang dalam mengontrol gerakannya atau mengolah gerakan tubuhnya dengan baik". Sujiono (2013, hlm. 188) mengemukakan bahwa "Kecerdasan fisik atau kinestetik adalah suatu kecerdasan dimana saat menggunakannya kita mampu melakukan gerakan-gerakan yang bagus berlari, menari, membangun sesuatu, semua seni dan hasta karya". Sejalan dengan pendapat Denok (2015, hlm. 67) menyatakan bahwa "Kecerdasan kinestetik itu merupakan kemampuan untuk menggunakan tangan, jari-jari, lengan, dan berbagai kegiatan fisik lain dalam menyelesaikan masalah, membuat sesuatu, atau dalam menghasilkan produk".

Disimpulkan dari beberapa pengertian diatas bahwa kecerdasan kinestetik adalah suatu kecerdasan kemampuan menggunakan tangan, jari-jari, dan lengan.

\section{Karakteristik Kecerdasan Kinestetik}

Mulyasari (2014, hlm. 377) mengemukakan bahwa "Ciri-ciri anak yang memiliki kecerdasan tubuh atau fisik yaitu anak yang suka berolahraga, anak juga dapat menirukan prilaku atau gerak-gerik orang lain, suka menari, suka kegiatan luar ruangan".

Yaumi, dkk (2016) Mengemukakan ciri-ciri pada anak yang memilki kecerdasan kinestetik, sebagai berikut:
1) Memiliki kemampuan yang baik untuk satu atau lebih jenis olahraga.

2) Senang bergerak dan memukul-mukul meja atau sesuatu ketika sedang duduk.

3) Senang meniru-niru sikap dan prilaku orang lain.

4) Senang bongkar pasang sesuatu.

5) Ketika melihat sesuatu, sering langsung menyentuh atau memegangnya

6) Senang berlari, melompt-lompat, bergulat, atau kegiatan lain yang sejenis.

7) Menunjukan keterampilan tentang kerajinan tangan .

8) Mengungkapkan sesuatu dengan cara dramatis.

9) Selalu menungkapkan perasaan fisik ketika bekerja.

10) Selalu bermain dengan tanah liat atau kegiatan taktis seperti menggambar dengan jari.

Berdasarkan dari ciri-ciri di atas pada dasarnya setiap anak memiliki kecerdasan kinestetik. Namun, yang membedakan adalah stimulus atau pendukung dari lingkungannya, kemampuan tersebut bisa terlihat begitu menonjol apabila stimulus yang diberikan guru atau orang tua tepat untuk anak.

\section{Perkembangan Motorik Anak Usia Dini}

Ketut Gading (2016, hlm. 02) mengemukakan bahwa "Perkembangan motorik adalah perkembangan dari unsur pengembangan dan pengendalian gerak tubuh, perkembangan motorik berkembang dengan kematangan syaraf dan otot yang meliputi motorik kasar dan halus". Perkembangan motorik terbagi menjadi dua, yaitu perkembangan motorik halus dan motorik kasar.

Menurut Samsudin (2008) mengemukakan bahwa "Motorik halus adalah kemampuan anak pra sekolah beraktifitas dengan menggunakan otot-otot halus (kecil) seperti menulis, dan menggambar". Sejalan dengan pendapat Sumantri (2005, hlm. 143) mengemukakan bahwa "Motorik halus adalah pengorganisasian penggunakan sekelompok otot-otot kecil seperti jari jemari dan tangan". Jadi dapat disimpulkan bahwa motorik halus 
adalah kegiatan yang menggunakan otot-otot halus pada jari dan tangan.

Menurut Yugang Qi, dkk (2018, hlm. 9) mengemukakan bahwa "Fine motor skills are important for children not only in he activities of daily living, but also for learning activities". Pendapat tersebut menjelaskan bahwa keterampilan motorik halus sangat penting bagi anak usia dini, tidak hanya dalam aktifitas kehidupan, tetapi juga untuk kegiatan belajar .

Saputra dan Rudyanto (2005, hlm. 117) menyatakan bahwa "Motorik kasar adalah kemampuan anak beraktifitas menggunakan otot-otot besarnya". Hal ini sesuai dengan pendapat Sujiono (2007, hlm. 1.17) bahwa "Motorik kasar adalah gerakan yang membutuhkan koordinasi sebagian besar bagian tubuh anak". Sejalan dengan pendapat Myrnawati (2017, hlm. 54) yang menyatakan bahwa "Keterampilan motorik kasar adalah gerakan besar otot lengan dan kaki". Jadi dapat ditarik kesimpulan dari beberapa pendapat ahli di atas bahwa motorik kasar adalah gerakan yang menggunakan otot besar seperti otot kaki dan otot lengan baik itu sebagian maupun semuanya.

Keterampilan menggunakan otot-otot besar bagi anak tergolong pada keterampilan gerak dasar. Agus Mahendra dan Yudha M (2006 : 21-22) mengemukakan keterampilan gerak dasar dibagi menjadi tiga yaitu: keterampilan lokomotor, keterampilan non lokomotor, dan manipulatif.

Myrnawati, CH Dkk (2017, hlm. 54) menjelaskan bahwa keterampilan motorik kasar memiliki tiga dimensi, yaitu keterampilan lokomotor, keterampilan nonlokomotor, dan manipulatif. Keterampilan lokomotor seperti berjalan, meluncur, melompat, dan berjingkak dan melompat. Keterampilan non- lokomotor adalah keterampilan dasar yang termasuk menyeimbangkan keterampilan, seperti berputar, dan bentuk statis yang dibentuk oleh gulungan, peregangan, memutar balik, dan membungkuk. Keterampilan manipulatif ditunjukan dengan melempar, menangkap, memimpin dengan kaki dan tangan, dan sepakan atau menendang.

\section{Unsur Keterampilan Motorik}

Sujiono (2007, hlm. 3-6) mengemukakan bahwa "Unsur-unsur kesegaran jasmani meliputi kekuatan, daya tahan, kecepatan, kelincahan, kelenturan, koordinasi, ketepatan dan keseimbangan". Sedangkan Toho Cholik Mutohir \& Gusril (2004) mengemukakan bahwa "Unsur-unsur yang terkandung dalam kemampuan motorik adalah kekuatan, koordinasi, kecepatan, keseimbangan, dan kelincahan". (hlm. 50).

1) Richard Decaprio (2013, hlm.47) menyatakan "Kekuatan didefinisikan sebagai kapasitas kekuatan otot ketika melakukan sebuah gerakan". Kekuatan otot tentunya harus dimiliki anak sejak dini. Apabila anak tidak memiliki kekuatan otot anak tidak dapat melakukan aktifitas bermain menggunakan fisik seperti berlari, melompat, melempar, memanjat, bergantung, dan mendorong.

2) Yasbiati \& Lutfi Nur (2016, hlm. 48) menyatakan "Koordinasi gerak merupakan yang mencakup dua atau lebih kemampuan perseptual pola-pola gerak". Gerak koordinasi ada dua, yaitu koordinasi mata dengan tangan dan koordinasi mata dengan kaki. Latihan koordinasi mata dengan tangan yang dapat diberikan pada anak usia dini yaitu menangkap bola yang dilempar. Sedangkan latihan koordinasi mata dengan kaki yaitu menendang bola.

3) Richard Decaprio (2013, hlm. 48) menyatakan "Kecepatan dalam pembelajaran motorik di sekolah diartikan sebagai kapasitas seorang anak untuk melakukan gerakan dari beberapa pola dalam waktu yang sangat cepat". Untuk melatih kecepatan pada anak bisa dilakukan dengan lari pada jarak pendek.

4) Keseimbangan adalah keterampilan seseorang untuk mempertahankan tubuh dalam berbagai posisi. Keseimbangan dibagi menjadi dua bentuk yaitu: keseimbangan statis dan dinamis. Keseimbangan statis merujuk kepada menjaga keseimbangan tubuh ketika berdiri 
pada suatu tempat. Keseimbangan dinamis adalah keterampilan untuk menjaga keseimbangan tubuh ketika berpindah dari suatu tempat ke tempat lain. Ditambahkannya bahwa keseimbangan statis dan dinamis adalah penyerdehanaan yang berlebih. Ditambahkannya kedua elemen keseimbangan kompleks dan sangan spesifik dalam tugas gerak individu.

5) Kelincahan adalah kemampuan seseorang mengubah arah dan posisi tubuh dengan cepat dan tepat pada waktu bergerak dari titik ke titik lain.

\section{Perkembangan Motorik Anak Usia 5-6 Tahun}

Menurut Sujiono, B dkk (2007), perkembangan kronologis, motorik kasar usia lima tahun dan enam tahun yaitu:

1) Berlari dan langsung menendang bola.

2) Melompat-lompat dengan kaki bergantian.

3) Melambungkan bola tenis dengan satu tangan dan menangkapnya dengan dua tangan.

4) Berjalan pada garis yang sudah ditentukan.

5) Berjinjit dengan tangan dipinggul.

6) Menyentuh jari kaki tanpa menekuk lutut.

7) Mengayuhkan satu kaki kedepan atau ke belakang tanpa kehilangan keseimbangan.

Menurut Peraturan Menteri Pendidikan

dan Kebudayaan Republik Indonesia nomor 137 tahun 2014 tentang Standar Nasional Pendidikan Anak Usia Dini. Pencapaian Perkembangan motorik kasar anak usia 5-6 tahun sebagai berikut:

1) Melakukan gerakan tubuh secara terkoordinasi untuk melatih kelenturan, keseimbangan, dan kelincahan.

2) Melakukan koordinasi gerakan matakakitangan-kepala dalam menirukan tarian atau senam.

3) Melakukan permainan fisik dengan aturan.

4) Terampil menggunakan tangan kanan dan kiri

5) Melakukan kegiatan kebersihan diri

Pencapaian Perkembangan motorik halus anak usia 5-6 tahun sebagai berikut:

1) Menggambar sesuai gagasannya
2) Meniru bentuk

3) Melakukan eksplorasi dengan berbagai media dan kegiatan

4) Menggunakan alat tulis dan alat makan dengan benar

5) Menggunting sesuai dengan pola 6 . Menempel gambar dengan tepat

6) Mengekspresikan diri melalui gerakan menggambar secara rinci

Maka dari beberapa uraian di atas, peneliti dapat simpukan bahwa yang masuk dalam kecerdasan kinestetik untuk melakukan kegiatan tari yaitu motorik kasar.

Salah satu bentuk kegiatan yang dapat dilakukan untuk meningkatkan kemampuan motorik kasar anak usia 5-6 tahun adalah dengan tari, sebagaimana disebutkan oleh Peraturan Menteri Pendidikan dan Kebudayaan Republik Indonesia Nomor 137 Tahun 2014 tentang Standar Nasional Pendidikan Anak Usia Dini yaitu melakukan gerakan tubuh secara terkoordinasi (untuk melatih kelenturan, keseimbangan, dan kelincahan), dan melakukan koordinasi gerakan (mata-kakitangan-kepala).

Hubungan Kecerdasan Kinestetik Anak Dengan Gerak Tari Kreasi Anak Asia Dini.

Banyak korelasi yang menghubungkan antara kedua variabel kecerdasan kinestetik dengan pembelajaran seni tari, karena keduanya sangat berkaitan dengan gerak. Menurut Hibana (2002:26) Kecerdasan kinestetik pada anak usia 5-6 tahun sangat berpengaruh dalam gerak tari, karena dengan gerakan-gerakan tari kreasi ini anak akan mengeluarkan tenaga. Dengan gerakangerakan tari tersebut anak akan mampu mengekspresikan dirinya lewat gerak tari dan irama musik sehingga motorik kasar anak bisa berkembang. Hubungan gerak tari kreasi dan Kecerdasan kinestetik anak yaitu gerak tari kreasi sangat berkaitan dengan Kecerdasan kinestetik anak, karena gerak anak menimbulkan gerakan-gerakan yang bermakna untuk anak, oleh karena itu apabila anak bisa bergerak apa saja akan menciptakan motorik anak jadi semakin kreatif dan berkembang. Berdasarkan teori tentang kecerdasan kinestetik dengan 
Teori Tari kreasi maka penelitian ini difokuskan pada aspek yang mengandung ciri kecerdasan kinestetik yaitu :

1) Melakukan gerakan tubuh secara terkoordinasi (kelenturan, keseimbangan, kelincahan)

2) Melakukan Koordinasi (gerakan mata kaki dan tangan kepala).

\section{METODE}

Desain penelitian ini menggunakan desain penelitian tindakan kelas (PTK). Menurut Arikunto (2010, hlm. 32) mengemukakan penelitian tindakan kelas adalah "Kegiatan yang diberikan oleh guru kepada anak agar melakukan sesuatu yang berbeda".

Subjek penelitian dalam penelitian ini yaitu anak kelompok B, yang berada pada rentang usia antara 5-6 tahun. Pada tahun ajaran 2017-2018 yang memiliki jumlah 13 anak. Pada penelitian tindakan kelas (PTK) kolaboratf ini peneliti dibantu oleh guru pamong yang mengajar di kelas tersebut, yang terbilang guru yang telah senior.

Tehnik pengumpulan data yang digunakan dalam penelitian peningkatan kecerdasan kinestetik anak usia dini melalui kegiatan tari kreasi manuk dadali di kelompok B Artanita Al-Khairiyah Kecamatan Cihideung Kota Tasikmalaya. Dalam penelitian ini menggunakan tehnik observasi dan dokumentasi.

Dari rumusan penelitian tersebut dapat ditentukan hasil persentase indikator keberhasilan secara individu yaitu kriteria indikator keberhasilan setiap siswa. Kemudian data yang telah dianalisis akan diinterpretasikan kedalam empat tingkatan (Djamarah, 1994). Adapun tingkatannya adalah sebagai berikut:

1) Kriteria sangat baik yaitu apabila ratarata nilai kemampuan keterampilan halus anak dalam rentang presentase nilai $85 \%-100 \%$

2) Kriteria baikyaitu apabila rata-rata kemampuan keterampilan motorik anak dalam rentang presentase nilai $75 \%-84 \%$

3) Kriteria cukup yaitu apabila rata-rata kemampuan keterampilan motorik anak dalam rentang presentase nilai $55 \%$ $74 \%$

4) Kriteria kurang yaitu apabila rata-rata kemampuan keterampilan motorik anak dalam rentang presentase nilai $<55 \%$.

\section{HASIL DAN PEMBAHASAN}

Penelitian ini dilaksanakan sebanyak tiga siklus, siklus I dilaksanakan pada hari Rabu 02 Mei 2018, sedangkan siklus II dilaksanakan pada hari Jumat 04 Mei 2018 dan siklus III dilaksanakan pada hari Senin 07 Mei 2018.

Perencanaan Pembelajaran

Perencanaan pembelajaran dilakukan sebelum pelaksanaan tindakan pada setiap siklusnya. Perencanaan pembelajaran diawali dengan koordinasi antara peneliti dengan guru kelompok A1 selaku peneliti kolaborator sekaligus observer. Koordinasi yang dilakukan yaitu menentukan tema dan sub tema pembelajaran yang akan digunakan dalam Rencana Pembelajaran Harian (RPPH) setiap siklusnya. Setelah peneliti dan guru kelas menentukan tema pembelajaran kemudian merumuskan RPPH. Indikator-indikator yang ada pada RPPH mengacu pada Peraturan Mentri Pendidikan dan Kebudayaan Republik Indonesia Nomor 137 Tahun 2014 Tentang Standar Pendidikan Anak Usia Dini dengan lingkup perkembangan Motorik Halus, karena penelitian ini bertujuan untuk meningkatkan keterampilan motorik halus anak usia dini melalui kegiatan playdough.

Perencanaan pembelajaran pada Penelitian Tindakan Kelas ini disajikan dalam tiga buah RPPH. Ketiga RPPH tersebut memiliki tema yang sama dan sub-sub tema yang berbeda-beda, RPPH yang digunakan pada siklus I bertemakan "Tanaman”, sub tema "tanaman hias" dan sub-sub tema "membentuk tanaman", RPPH yang digunakan pada siklus II dengan tema yang sama yaitu "tanaman" sub-sub tema yang sama yaitu "tanaman hias" dan sub-sub tema yang berbeda yaitu "bunga matahari", sedangkan RPPH yang digunakan pada siklus III memiliki tema yang sama dengan siklus I dan siklus II yaitu "Tanaman" dengan sub-sub tema "Tanaman Bunga". 
Adapun untuk hasil kinerja guru dalam perencanaan pembelajaran, dapat dilihat pada grafik berikut ini:

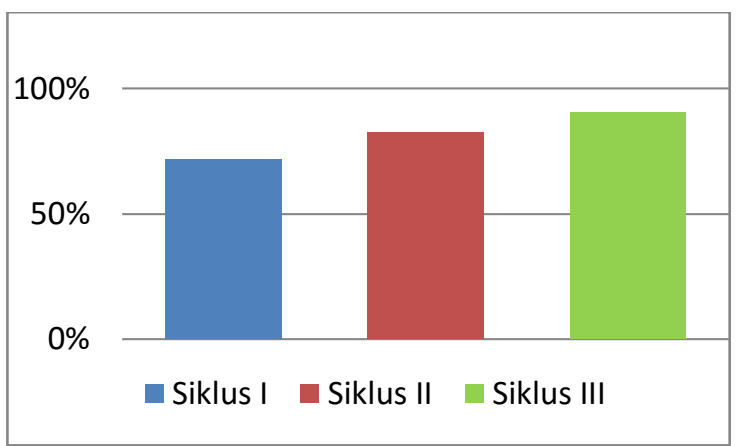

Kinerja guru dalam pembuatan RPPH mengalami peningkatan dalam setiap siklusnya dengan uraian sebagai berikut: pada siklus I nilai kinerja yang diperoleh guru dalam membuat RPPH adalah: $71,875 \%$ (belum mencapai indikator keberhasilan yang telah ditentukan). Kelemahan pada RPPH siklus I adalah kesulitan peneliti dalam menentukan cara-cara penanaman pembiasaan di kegiatan awal, inti, istirahat dan akhir kegiatan pembelajaran. Pada siklus II kekurangan pada $\mathrm{RPPH}$ tersebut dapat diatasai oleh guru sehingga mengalami peningkatan sebesar $10,93 \%$ menjadi $82,81 \%$. Adapun kelemahan pada siklus II baik itu aspek perencanaan kegiatan bidang pengembangan, perencanaan pengelolaan kegiatan, perencanaan penilaian proses dan hasil, serta perbaikan pada penampilan dokumen dapat diatasi pada siklus III sehingga mengalami peningkatan sebesar $7,81 \%$ menjadi $90,62 \%$. Sehingga dapat disimpulkan bahwa perencanaan pembelajaran dalam pembuatan RPPH pada setiap siklusnya mengalami peningkatan dengan baik.

\subsubsection{Penggunaan Playdough}

Penggunaan playdough merupakan pelaksanaan dari Penelitian Tindakan Kelas ini. Dalam melakukan kegiatan pembelajaran menggunkan playdough peneliti menyediakan beberapa gambar yang bisa digunakan untuk membantu peneliti dalam menjelaskan tentang kegiatan yang dilakukan anak pada setiap siklusnya, dengan memilih gambar yang memiliki konten yang sama dengan tujuan dari penelitian ini, adapun gambar yang dapat membantu peneliti yaitu gambar tanaman bunga dan bagian-bagiannya (batang, daun dan bunga) dengan terpisah untuk mengenalkan bagian bunga agar anak memiliki pengetahuan dalam membentuk bagian bunga pada indikator membentuk menggunkan alat cetak. Peneliti menyediakan gambar tersebut berdasarka tema dan subtema yang telah direncanakan pada RPPH.

Adapun peningkatan kemampuan guru dalam menggunkan playdough dapat dilihat pada grafik berikut ini:

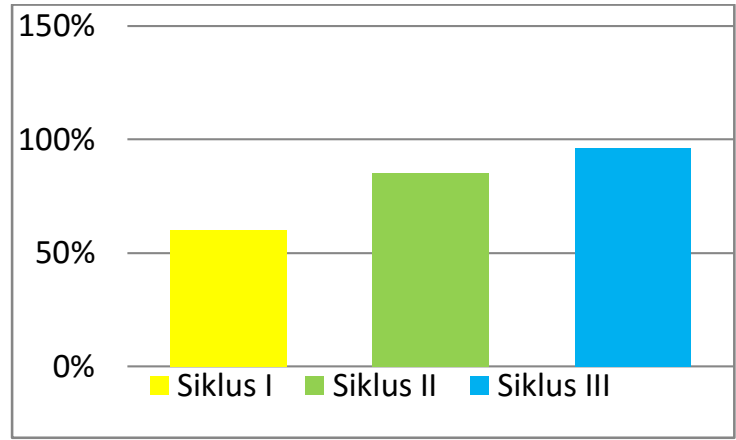

sedangkan keterampilan motorik halus anak dengan indikator membentuk bebas adalah berikut ini:

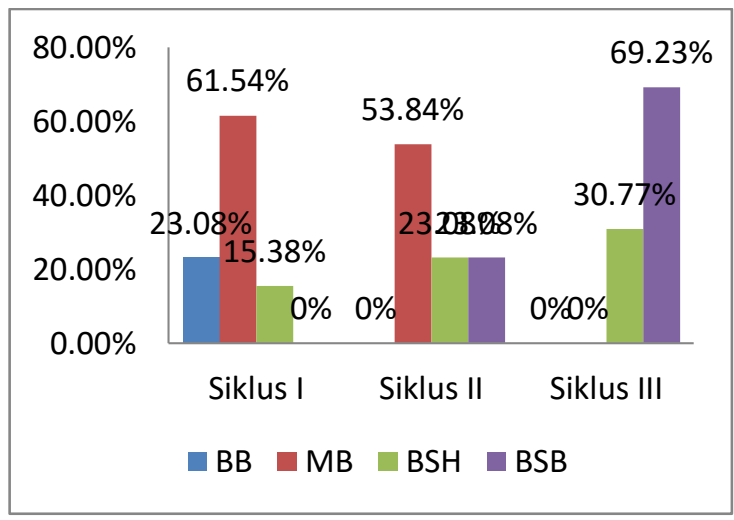

Indikator membentuk bebas terarah yaitu

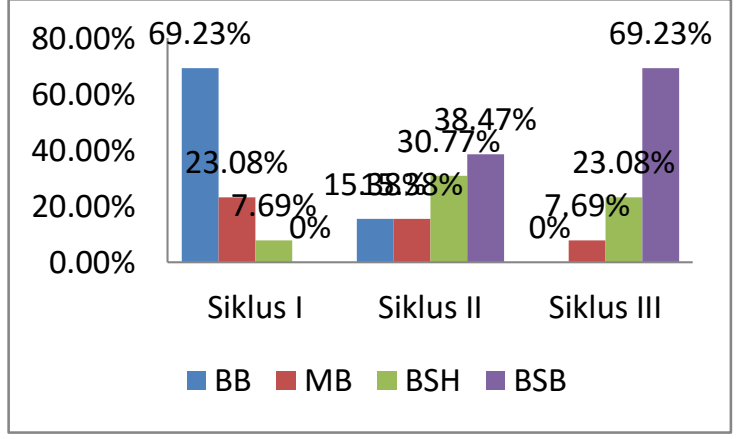

Indikator membentuk menggunakan alat cetak yaitu: 


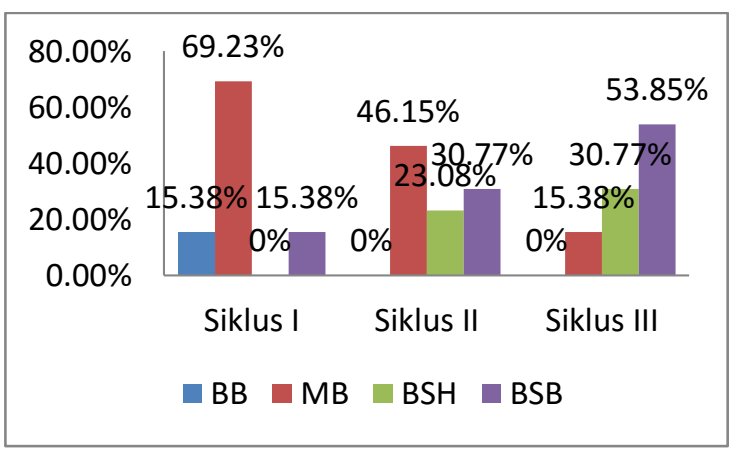

Dan indikator mengelompokkan bentuk yaitu:

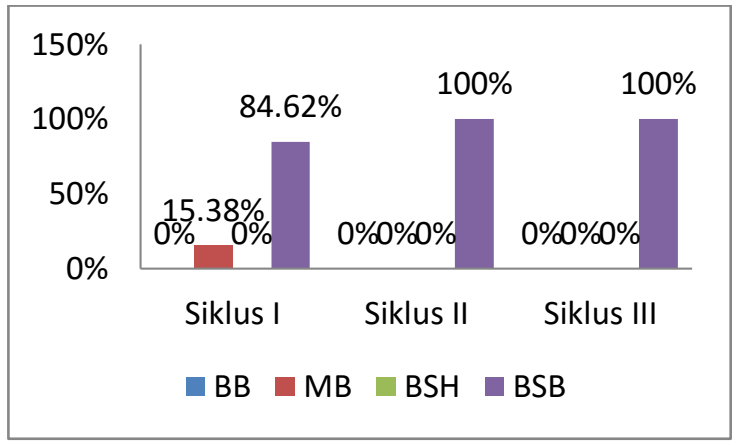

Peningkatan yang terjadi pada setiap indikatornya menandai bahwa penelitian ini berhasil karena telah meningkatkan keterampilan motorik halus anak dengan menggunakan playdough. Peningkatan yang dijumpai pada anak ini berlangsung secara bertahap. Dimana berdasarkan penelitian yang telah dilakukan keterampilan motorik halus anak didominasi oleh keterampilan mengelompokkan bentuk, hal ini sejalan dengan teori yang dikemukakan oleh Pieree van Hiele dan Dina van Hiele-Geldof (dalam Ministry of Education Ontario, 2008, Hlm. 18) menyatakan bahwa anak usia dini berada pada tingkatan pertama atau level 0 atau visualisasi yakni pada tingkatan ini anak akan mengenali dan mengidentifikasi macam-macam bentuk berdasarkan penampilan fisik tanpa mengidentifikasi karakteristik dari bentuk itu sendiri. Hal inipun ditemukan dilapangan dimana sebagian besar anak pada siklus I dan semua anak pada siklus II dan siklus III sudah mampu mengelompokkan bentuk tetapi tidak dibarengi dengan kemampuan membentuk bebes terarah dan membentuk menggunakan alat, hal ini dikarenakan anak sudah mampu mengidentifikasi bentuk tanpa mengetahui nama bentuk itu sendiri, tetapi mereka mengelompokkan bentuk tersebut berdasarkan apa yang mereka lihat.

\section{KESIMPULAN}

Berdasarkan penelitian yang telah dilakukan, dapat disimpulkan bahwa playdough dapat meningkatkan keterampilan motorik halus anak kelumpok A1 TK Artanita Kecamatan Cihideung Kota Tasikmalaya. Hal tersebut dapat dilihat dari meningkatnya jumlah presentase pada setiap aspek penelitian, baik itu perencanaan, pembelajaran, dan keterampilan motorik halus anak.

Perencanaan yang dilakukan oleh peneliti sekaligus guru dalam penelitan ini mengalami peningkatan pada setiap siklusnya dengan kenaikan sebesar 10,93\% dari siklus I ke siklus II dan kenaikan sebesar 7,80\% pada siklus II ke siklus III sehingga kemampuan akhir guru dalam perencanaan pembelajaran sebesar 90,63\% dengan kriteria sangat baik. Sedangkan untuk pelaksanaan pembelajaran mengalami kenaikan sebesar $8,17 \%$ dari siklus I ke siklus II dan kanaikan sebesar 17,33\% dari siklus II ke siklus III sehingga kemampuan akhir guru pelaksanaan pembelajaran sebesar 91,08\% dengan kriteria sangat baik. Begitu pula dengan penggunaan aspek membentuk sesuai dengan tema menggunakan playdough pada setiap siklusnya mengalami kanaikan sebesar $25,41 \%$ dari siklus I ke siklus II dan kenaikan sebesar $10,42 \%$ dari siklus II ke siklus III sehingga kamampuan akhir guru dalam penggunaan playdough sebesar 95,83\% dengan kriteria sangat baik.

Ketampilan motorik halus pada anak mengalami peningkatan setelah menggunakan playdough pada setiap indikatornya. Indikator yang pertama yaitu membentuk bebas mengalami peningkatan yang signifikan dengan kemampuan akhir 30,77\% pada kriteria berkembang sesuai harapan dan sebesar $60,23 \%$ pada kriteria berkembang sangat baik. Indikator yang kedua yaitu membentuk bebas terarah mengalami peningkatan dengan kemampuan akhir sebesar 7,69\% pada kriteria mulai berkembang, $23,08 \%$ pada kriteria berkembang sesuai harapan, dan $69,23 \%$ pada kriteri berkembang sangat baik. Indikator yang ketiga membentuk menggunkan alat cetak mengalami peningkatan dengan kemampuan 
akhir sebesar $15,38 \%$ pada kriteria mulai berkembang, $30,77 \%$ pada kriteria berkembang sesuai harapan, dan sebesar $53,85 \%$ pada kriteria berkembang sangat baik. Begitupun dengan indikator yang ke empat mengelompokkan bentuk mangalami peningkatan yang pesat dengan kemampuan akhir anak sebesar $100 \%$ pada kriteria berkembang sangat baik.

\section{SARAN}

Bagi guru TK Artanita,

Guru harus mampu menyajikan pembelajaran yang menyenangkan serta menggunakan lat pembelajran yang menarik perhatian anak sehingga anak dapat mengikuti pembelajaran dengan baik, dengan begitu anak dapat mlakukan kegiatan pembelajara yang menyenangkan.

Bagi peneliti lanjutan

Bagi peneliti lanjutan, hasil peneliti ini dapat digunakan sebagai salah satu referensi tentang peningkatan ketarampilan motorik halus anak.

\section{DAFTAR PUSTAKA}

Agung. (2016). Penerapan Metode Bermain melalui Media Playdough untuk Meningkatkan Kemampuan Motorik Halus Anak. Jurnal. Vol 4 no 2

Andang, Ningsih. (2015). Education Games. Yogyakarta: PT Pilar Media.

Arikunto, S, dkk. (2013). Penelitian Tindakan Kelas. Jakarta: Bumi Aksara

Beaty, Janice. J. (2013). Observasi Perkembangan Anak Usia Dini. Jakarta: PT Kencana

Dario, C. \& Milena. (2011). Gross Motor Development and Physical Activity in Kindergarten age Children. Conaplin Journal: Indonesian Jaurnal of Pediatric Obesity, 6(S2): 33-36. doi: http://dx.doi.org/ 10.3109/17477166.2011.613661

Difatiguna, S. (2015) Pengaruh Aktivitas Bermain Menggunakan Playdough terhadap Kemampuan Motorik Halus Anak. Jurnal: Fakultas Ilmu Pendidikan Universitas Lampung
Djamarah, S, B.(1994). Strategi Belajar Mengajar. Jakarta: Rineka Cipta

Ismail, A. (2006). Education Games. Yogyakarta: PT Pilar Media.

Martha Christiant. (2007). Anak dan Bermain. Jurnal Club Prodi PGTK UNY dan Majalah Edu TOT PGTK UNY

Mc. Taggart, R dan Kemmis, S. (1990). The Action Research Planner. Melbourne. Deakin University.

Ministry of Education Ontario. (2008). Geometry and Spatial Sense Grades 4 to 6 Ontario: Queen's Printers for Ontario

Mulyasa, H, E. (2012). Praktik Penelitian Tindakan Kelas. Bandung: PT Remaja Rosdakarya

Nicholas, D. (2009). Peran Media Playdough untuk Meningkatkan Kreativitas Anak Usia Dini. Jurnal: UPBJJ Semarang

Novitasari, Noni. (2009). Efektivitas Media Playdough Untuk Meningkatkan Prestasi Belajar Dalam Pembelajaran IPA, (Skripsi). Sarjana Pendidikan, Universitas Pendidikan Indonesia, Bandung.

Pamadhi, Hajar. 2008. Seni Ketrampilan Anak. Universitas Terbuka: Jakarta.

Paillard. (1982). The Contribution of peripheral and Cantral Vision to Visually Guide Reaching. Conaplin Journal: Indonesian Journal of Museum Education,189.doi:article: http://dx.doi.org/10.1080/10598650.200 2.11510455

Peraturan Pemerintah dan Kebudayaan Republik Indonesia. (2014). Kurikulum 2013 Pendidikan Anak Usia Dini. Jakarta: Mentri Kebudayaan Republik Indonesia.

Pitamic. (2013). Child's Play. Yogyakarta: Pustaka Pelajar.

Rismayanthi, C. (2013). Mengembangkan Keterampilan Gerak Dasar Sebagai Stimulasi Motorik Bagi Anak Taman Kanak-Kanak Melalui Aktivitas Jasmani. Jurnal: JPJI, Volume 9, Nomor 1, April 2013 
Roberta, L. (1987). Knowledge About Hand Shaping and Knowlage About Object. Conaplin Jaurnal: Indonesian Jaournal of Motor Behavior, 188. vol 19 no 2

Saputra M. Yudha dan Rudyanto. 2005.

Pembelajaran Kooperatif Untuk Meningkatkan Keterampilan Anak TK. Jakarta: Departemen Pendidikan Nasional.

Setianingrum. (2004). Perkembangan Motorik Halus Anak Usia 3-4. ejournal: PGPAUD FIP UNY, vol 3 no 2

Sugiyono. (2013). Metode Penelitian Pendidikan. Bandung: Alfabeta

- (2014). Metode Penelitian. Bandung: Alfabeta

Sujiono, Y. N, dkk. (2013) Konsep Dasar Pendidikan Anak Usia Dini. Jakarta: PT Indeks

- (2011). Metode Pengembangan Kognitif. Jakarta: Universitas Terbuka

Sunardi, O. (2017). Pengaruh Menggambar Dekoratif Terhadap Kemampuan Motorik Halus. (Skripsi). Sekolah Sarjana Pendidikan, Institut Agama Islam Negeri Raden Intan, Lampung

Sumantri. (2005). Model Pengembangan Keterampilan Motorik Anak Usia Dini.

Jakarta: Depdiknas.

Sumanto. (2005). Pengembangan Kreativitas Seni Rupa Anak TK, Jakarta:

Departemen Pendidikan Nasional

Undang-undang No 20. (2003), Tentang

Sistem pendidikan nasional. Jakarta: Republik

Indonesia 